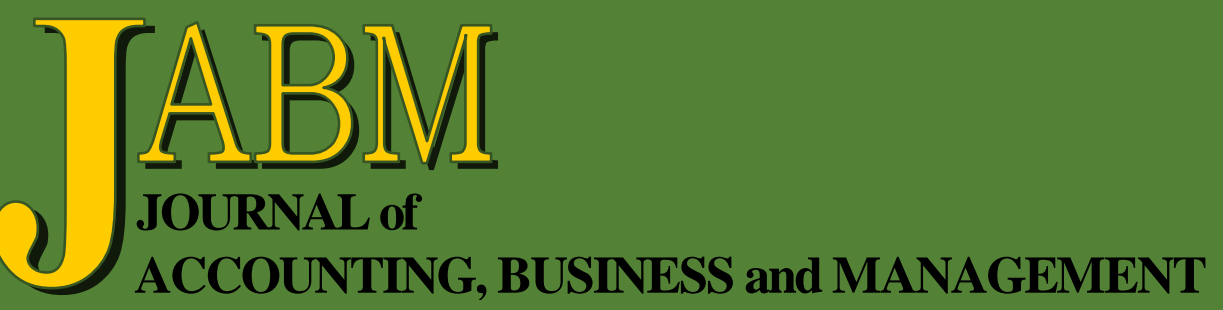

An Analysis of Management Accounting System Development from the Structuration Theory Viewpoint

Anthony Moung Yin Chan, Paul Lo and Kong Ng

Impact of Total Asset Turnover Ratios on Equity Returns: Dynamic Panel Data Analyses

Jeanne-Claire Patin, Matiur Rahman and Muhammad Mustafa

The Impact of Audit Committees on US Nonprofit Organizations'

Governance

Husam Abu-Khadra

Implicit Taxes Amid Race to the Bottom in a Global Tax Game

Igor Semenenko, Junwook Yoo and Parporn Akathaporn

The Adoption of Financial Accounting Standards for Small Medium Enterprises by Muslim Entrepreneurs

Muslichah, Sunarto, Anang Amir Kusnanto, Sri Indrawati and Hariyanto

The Impact of E-Procurement Systems in the Biomedical Industry

A. Seetharaman, Nitin Patwa, Simon Lai Koek Wai and Ahammed Shamir

After-Tax Discounting: A Research Edge

Hongtao Guo

Rules-Based Accounting Standards and SEC Enforcement

Devon Baranek 


\title{
After-Tax Discounting: A Research Edge
}

Hongtao Guo*

\begin{abstract}
This research note addresses after-tax discounting for pricing assets. Specifically, it analyzes the appropriate way to discount after-tax payoffs from assets that trade in capital markets in which both taxable and tax-free investors can buy and sell both taxable and tax-free instruments. The effect of the tax status of the investor and the tax status of the financing tool that an investor uses on price of an asset are discussed. Secondly, it derives the proper after-tax discount rate to use in the risk neutral valuation method for pricing assets that have state-contingent payments, typically structured in a lease based transaction. Dynamic state-contingent payoffs and cash flow processes are developed. Pre-tax discounted price, after-tax discounted payoffs are considered, then after-tax discount rate is derived. Included in this analysis of state-contingent discounting is the effect of depreciation expense, the only expense associated with the use of the asset, on after-tax discount rates.
\end{abstract}

Keywords: tax analysis, discount rate, asset pricing, lease, state-contingent payoffs, depreciation.

\section{INTRODUCTION}

In every corporate capital investment decision, the tax implications of the investment's financial structure are central features in the assessment of the asset's after-tax value to the corporation. This is especially true with lease financed investments. In lease finance, setting the schedule of rental payments from the lessee to the lessor defines the way that any potential tax benefits to either party arising from an investment or its method of finance are shared. At the same time, an asset purchase by a lessor is usually debt financed and the debt is secured with the lease and the rental payments due from the lessee. Thus prices for real assets, loan rates to lessors, and rental rates for lessees are all set simultaneously in trading markets for assets, credit and lease. ${ }^{1 \dagger}$

Many reasons exist for asset leasing. Leasing allows for specialization in asset investment by separating holding title to an asset from using an asset to extract its capital services. Title holders specialize in identifying productive assets, finding both efficient sources for assets and efficient users of the assets' capital services, negotiating prices for both asset purchase and use, and securing assets' finance. Asset users specialize in assets' employment: managing production, selling output, financing trade, and providing customer services. The two activities are quite different. The first is directed at markets for real assets and capital finance; the second is focused on production and marketing to customers. Leasing allows specialized title holders to

\footnotetext{
* Associate Professor of Accounting, Department of Accounting and Finance, Bertolon School of Business, Salem State University, Salem MA 01970. Phone: 978-542-2383. E-mail: hguo@salemstate.edu.

${ }^{1}$ Jarrow, R. A., \& Rudd, A. T. (1983, January). Option pricing. Homewood, Illinois: Richard D. Irwin, Inc.
} 
provide assets to specialized asset users. Although leasing predates corporate taxation, tax analysis is now a key feature of lease finance.

This note addresses two issues related to corporate taxes, leases and pricing risky assets. The first issue concerns the way to discount after-tax payouts from assets that trade in capital markets in which both taxable and tax-free investors can buy and sell both taxable and tax-free instruments. The potential effect on prices created by the tax status of the investor and the tax status of the financing instruments that an investor can issue are both important considerations. The second issue concerns deriving proper after-tax discount rates to use in the equivalent risk neutral valuation method for pricing assets that have state-contingent payments. Included in this analysis of statecontingent discounting is the effect of depreciation schedules on after-tax discount rates. After-tax discounting is considered in the next section; state-contingent, after-tax valuation follows in the sections after that. Then lease option payoffs are considered.

\section{TAXES AND TAX ARBITRAGE}

The analysis of the tax impact on discount rates and asset prices uses a simple analysis based on the existence of both investors who pay taxes and those who do not, and the existence of both taxable bonds and tax-free bonds as potential methods of financing an asset purchase. To set up the analysis, consider two investors, one taxable and the other tax-free. Also consider two assets, a treasury bond with taxable coupons and a municipal bond with tax-free coupons. The treasury bond pays a coupon of $\$ 10$ in one year and a final $\$ 10$ coupon plus $\$ 100$ principal in two years. This bond has no default risk. The municipal bond pays a $\$ 6$ coupon in one year and a final $\$ 6$ coupon plus $\$ 100$ principal in two years. This bond also has no default risk either. First the influence of the investors' tax status is analyzed, and then the influence of the tax status of the bonds they issue to finance investments is considered.

Both taxable and tax-free investors use the risk-free rate to price default-free instruments. Assume the risk-free rate is 0.10 on a yearly basis. The tax-free investor prices the treasury bond as:

$100=10 /(1.10)+110 /(1.10)^{2}$

The municipal bond's value to the tax-free investor is:

$96.3636=6 /(1.1)+106 /(1.1)^{2}$

The municipal bond's value to a tax-free investor is lower than the treasury bond's price due to the municipal bond's smaller coupon payments.

Now suppose the taxable investor discounts after-tax payments with an after-tax discount rate. This taxable investor first deducts the taxes from the treasury bond's coupon payments and then discounts the after-tax payouts of the bond with an aftertax discount rate of $(0.10)(1-T)=0.06$, where the investor's tax rate is $T=0.40$. With these assumptions, the value of the treasury bond to the taxable investor is:

$100=10(1-0.4) / 1.06+(10(1-0.4)+100) /(1.06)^{2}$

This makes the taxable and tax-free investor assign equal values to the treasury bond. Note that this pricing method gives the same result for every tax rate. For example, if another investor's tax rate is $T=0.20$, the treasury's value to that investor is

$100=10(1-0.2) / 1.08+(10(1-0.2)+100) /(1.08)^{2}$

Thus all taxable investors and the tax-free investor agree upon the same price in the market. For the taxable investor, the municipal bond's payouts after tax equal its payouts before tax. Using the after-tax discount rate for the after-tax payout, the municipal bond's after tax value for a taxable investor is:

$100=6 / 1.06+106 /(1.06)^{2}$ 
This price makes the taxable investor whose tax rate is $T=0.40$ indifferent between the treasury bond and the municipal bond on an after-tax basis. The investor with a tax rate of $T=0.20$ would value this municipal bond as:

$96.4335=6 / 1.08+106 /(1.08)^{2}$

Thus this low-tax investor would not purchase the municipal bond. In other words, simply paying taxes is not a sufficient condition for investing in taxed assets.

Without considering the method of finance, an investor who pays no taxes would not buy the municipal bond at par because its coupon payments are less than the treasury bond's. However, a tax-free investor who can issue a tax-free bond would be indifferent about buying a municipal bond at this price because the financing cost would equal the investment return. Of course, if this issuer of tax-free bonds is also a tax-free investor, then a treasury bond purchase would be preferred unless its purchase is proscribed. $2 \$ 5$

One implication of this analysis is that the bond market's marginal investor is taxable and that issuers of tax-free instruments cannot arbitrage taxable and tax-free bond markets by issuing tax-free bonds to finance purchases of taxable bonds. Another implication follows this. The full value of an investment opportunity depends upon its method of finance.

The importance of investment financial structure works through arbitrage between taxable bonds and tax-free bonds. Suppose an investor could issue tax-free bonds to finance investments in taxable instruments. Then that issuer of tax-free instruments could issue a bond with yearly coupon of $\$ 6$ to finance fully the purchase of a treasury bond with a yearly coupon of $\$ 10$. Both instruments have an initial value of $\$ 100$ in a market initially dominated by taxable investors. The issuer of the tax-free bond could use the treasury bond as collateral for the tax-free bond so the tax-free bond would be a default-free instrument. Unless this tax arbitrage practice is limited, such arbitrage would result in issuers of tax-free bonds owning all the treasury bonds. However, the IRS has rules that limit issuers of tax-free bonds from arbitraging taxable bond markets by issuing tax-free instruments to finance purchases of securities taxable to other investors. This appears to limit arbitrage trading by issuers of tax-free bonds enough to prevent capital market prices moving to an equilibrium based on pre-tax payouts. With tax arbitrage by issuers of tax-free bonds circumscribed, tax arbitrage by taxable issuers is not possible either because all bonds are priced at after-tax prices (AlAbadi \& Al-Sabbagh, 2006).

The limit to arbitrage outlined above suggests that both taxable and tax-free instruments can trade in a capital market with taxable and tax-free investors and issuers if simple tax arbitrage for tax-free bond issuers is limited. Because of this, both taxable and tax-free bonds appear to trade on an after-tax basis. Moreover, because bonds and real assets are substitute investments, this affects corporate valuations of real asset investments too. The next sections show how to derive discount factors for taxable investors in tax arbitrage-limited markets in which state-contingent claims also trade.

${ }^{2}$ If a taxable investor can issue bonds that are tax-free for other investors, another potential arbitrage opportunity arises if the issuer can deduct bond interest paid and use the tax deduction to apply against other taxable income. Then the investor can buy a tax-free bond for $\$ 100$, issue a tax-free bond for $\$ 100$, and own a position worth the difference between taxfree coupons received and tax-free coupons paid. This trade is profitable as long as the tax deductions can be used. Same argument can be extended in terms of the impact of tax credit imputation on a taxable investor. 


\section{AFTER-TAX DISCOUNT FACTORS FOR STATE-CONTINGENT PAYMENTS}

To extend the pricing analysis to more complex investment alternatives, consider a one-period contract that makes state-contingent payments in a binomial pricing framework. At the end of one-period, the asset value moves either up or down in value and makes its final payment at the outcome that occurs. This up or down increment in final payment amount relative to the initial investment amount is taxable for a taxable investor and not taxed for a tax-free investor. Tax losses are assumed to be usable against other gains for a taxable investor.

The pricing equation for a taxable investor equates the current price of the asset to the present expected value of its possible final payments. For binomial pricing, only two outcomes are required.

$V(0)=\pi(V(u)-T(V(u)-V(0))) /(1+r(0))+(1-\pi)(V(d)-T(V(d)-V(0)))$ $/(1+r(0))$

Where

$V(0)$ : initial contract price;

$\pi \quad$ : equivalent risk-neutral up move probability;

$V(u)$ : up state payment;

$V(d)$ : down state payment;

$T$ : marginal tax rate; and

$r(0) \quad$ : after-tax, one-period risk-free discount rate.

This equation gives the after-tax contingent payments when the tax basis of the investment is the initial price $V(0)$. The expression impounds the assumption that any tax loss can always be used by the taxable investor. A tax-free investor has no tax obligation from the state-contingent payments, which means that for a tax-free investor, $T=0$ and $r(0)$ equals the pre-tax risk-free rate $r_{l}(0)$ in the equation for $V(0)$.

Rearranging terms in the after-tax price equation gives the investment's present expected value with the tax basis $V(0)$ removed from the payment terms on the right side.

$V(0)-(T V(0) /(1+r(0)))=\pi V(u)(1-T) /(1+r(0))+(1-\pi) V(d)(1-T) /(1+r(0))$

$V(0)=\pi V(u)(1-T) /(1+r(0)-T)+(1-\pi) V(d)(1-T) /(1+r(0)-T)$

This gives the initial contract value for a taxable investor without the investment basis in the payment terms on the right side of the equation.

To find the appropriate after-tax discount rate for this investment, compare the after-tax price equation for a taxable investor with the price equation for a tax-free investor. This comparison is based on the conclusion in the previous section that both taxable and tax-free investors pay the same price based on markets dominated by taxable investors. For a tax-free investor, the contract value is

$$
V(0)=\pi V(u) /\left(1+r_{1}(0)\right)+(1-\pi) V(d) /\left(1+r_{1}(0)\right)
$$

In a tax arbitrage-limited market where the marginal investor is taxable, both taxable and tax-free investors accept the same price. In this case, the taxable investor's price equation can be set equal to the tax-free investor's price equation to solve for $r(0)$ in terms of $r_{l}(0)$.

Setting the two expressions for $V(0)$ equal to each other gives

$(\pi V(u)+(1-\pi) V(d))(1-T) /(1+r(0)-T)=(\pi V(u)+(1-\pi) V(d)) /\left(1+r_{1}(0)\right)$

Cross multiply the denominators and solve for the after-tax discount rate $r(0)$ in terms of the tax-free discount rate $r_{l}(0)$. The result is:

$$
r(0)=r_{1}(0)(1-T)
$$


This means that the taxable discount factor for after-tax payments that are adjusted for the initial basis by subtracting the basis from the payment before the tax is calculated is

$$
1 /(1+r(0))=1 /\left(1+r_{1}(0)(1-T)\right)
$$

This is the same result as the one in previous tax analysis of taxable and tax-free risk-free investors where issuers of tax-free bonds are limited in tax arbitrage trading. The analysis here shows that, to use this discount rate adjustment for taxable investors more generally, requires that the basis be included in the payment terms. This topic is expanded in the next section.

The taxable discount factor for after-tax payments without the basis included in the payment terms (e.g., for a simple, unhedged forward contract with a purchase price and tax basis of zero) is again calculated from taxable and tax-free valuations. For a taxable investor:

$$
V(0)=\pi V(u) /(1-T) /(1+r(0))+(1-\pi) V(d)(1-T) /(1+r(0))
$$

and for a tax-free investor

$$
V(0)=\pi V(u) /\left(1+r_{1}(0)\right)+(1-\pi) V(d) /\left(1+r_{1}(0)\right)
$$

Equating the two expressions for $V(0)$ and solving for $r(0)$ in terms of $r_{l}(0)$ gives:

$$
\begin{aligned}
& 1 /(1+r(0))=1 /\left(\left(1+r_{1}(0)\right)(1-T)\right) \\
& r(0)=r_{1}(0)(1-T)-T
\end{aligned}
$$

This discount rate exactly removes the tax effect from the payments so taxable and tax-free investors value the payments equally. Note that discounting in this fashion means that taxable and tax-free investors would price taxable payments equally but taxfree investments would not be purchased by a tax-free investor (given the same financing terms) because the price established by taxable investors would be too high (the taxable investors' discount factor is too large with (1-T) in the denominator).

\section{A UNIFIED AFTER-TAX DISCOUNT SOLUTION}

Now we can return to the taxable bond and a taxable investor set up to show how the after-tax discount factor can be used for a two-period risk-free bond. Label the bond's period 1 price $V(u)$ in state up (one-period before maturity), its coupon payment $C$, and its maturity principal value $B$. Then for a taxable investor, if the whole purchase basis can be subtracted in the final payment term, the price in period 1 , state $u$ is:

$$
\begin{aligned}
& V(u)=(C+B-T(C+B-V(0))) \pi /(1+r(u))+(C+B-T(C+B-V(0)))(1-\pi) /(1+r(u))) \\
& V(u)=(C+B-T(C+B-V(0)) /(1+r(u))
\end{aligned}
$$

in which the one-period risk-free discount factor for the after-tax payments starting from state $u$ is $1 /(1+r(u))$. For a tax-free investor, the price is

\section{$V(u)=(C+B) /(1+r(u))$}

Because for a tax-free investor, $T=0$ and the discount rate is the market risk-free rate $r_{1}(u)$ in the up state $u$. These two pricing equations, one for a taxable investor and one for a tax-free investor, together give the proper after-tax discount factor in terms of $r_{1}(u)$. The solution is

$$
\begin{aligned}
& 1 /(1-r(u))=1 /\left((1-T)\left(1+r_{1}(u)\right)+T_{V}\right) \\
& r(u)=(1-T) r_{1}(u) \\
& \text { The rate solutions for the down state's price at time } 1 \text { give } r(d)=(1-T) r_{1}(d) .
\end{aligned}
$$


Now move back one-period from $V(u)$ and $V(d)$ to find the initial period's aftertax discount factor if the bond's initial price is $V(0)$. The following expression is the initial price equation for a taxable investor. Here $r(0)$ is the time 0 risk-free discount rate for a taxable investor.

$V(0)=(\pi(C+V(u)-T(C+V(u)-V(0)))+(1-\pi)(C+V(d)-T(C+V(d)-V(0)))) /(1+r(0))$

This equation simplifies to:

$$
V(0)=(((C+V(u)) \pi+(C+V(d))(1-\pi))(1-T)+T V(0)) /(1+r(0))
$$

For a tax-free investor, the equivalent expression at time 0 is:

$V(0)=((C+V(u)) \pi+(C+V(d))(1-\pi)) /\left(1+r_{1}(0)\right)$

Here $r_{l}(0)$ is the time 0 risk-free rate for a tax-free investor. The two equations can be used together to eliminate $V(0)$ and solve for $r(0)$ in terms of $r_{l}(0)$. This gives,

$1+r(0)=\left(1+r_{1}(0)\right)(1-T)$,

which is the same result as before for contingent claims but with period-specific discount rates.

\section{DISCOUNTING AND OPTION EXERCISE}

In leasing, frequently a key feature of the contract is a European option at the end of the lease that allows the lessee to purchase the leased asset from the lessor for a fixed price. The exercise of this option likely is a tax event for the lessor. It may also be a tax event for the lessee, but to keep the development simple, this analysis assumes that the lessee is a tax-free entity. The after-tax analysis focuses on the lessor's discount rates for purchase option outcomes. The tax framework corresponds to the lease-toservice contract type of complex lease discussed before except that only a simple purchase option is considered here. To further simplify the analysis, it is assumed that tax deductions earned can always be used by a taxable lessor. A taxable lessor is contrasted to a tax-free lessor to solve for appropriate after-tax discount rates.

Assume an asset valued initially for $V(0)$ is purchased by a lessor who finances most of the asset's purchase price with a loan that has a principal value $B(0)$ and a coupon rate of $C$ per period. The amount $V(0)-B(0)$ is the lessor's cash equity investment in the transaction. Thus the transaction is a leveraged lease for the lessor. At the end of the lease, the lessee can purchase the asset for a fixed price $Z$. The lease rental per period is $R$. Now consider a one-period binomial lease valuation problem. The possible outcomes are shown in the table below.

Figure 1

Lessor's Lease Option Exercise Date Payoffs

\begin{tabular}{lcc}
\hline & Lease Exercise $(\boldsymbol{V}(\boldsymbol{s})>\boldsymbol{Z})$ & No Lease Exercise $(\boldsymbol{V}(\boldsymbol{s}) \leq \boldsymbol{Z})$ \\
\hline Taxable Lessor & $V(0)+(\mathrm{Z}+\mathrm{R}-(V(0))(1-T)$ & $V(0)+(V(s)+\mathrm{R}-(V(0))(1-T)$ \\
Tax-free Lessor & $Z+R$ & $V(s)+R$ \\
\hline
\end{tabular}

This table shows the payoffs for both a taxable lessor and a tax-free lessor if the lessee chooses its rational asset purchase option exercise alternative. The table compares the payoffs for both a taxable lessor and a tax-free lessor. The lessee is assumed to be a tax-free entity. For a taxable lessor who owns the leased asset, the payoff if the lessee exercises the purchase option is the initial book value of the asset plus the after tax difference between the exercise price plus the final rent payment and the asset's initial book value. ${ }^{3 * *}$ If the option is not exercised, the payoff for a taxable lessor is the initial book value of the asset plus the after tax difference between

\footnotetext{
3 When the same corporate tax rate applies for depreciation tax savings and capital gains and
} losses for asset sales, the tax effect of depreciation can be ignored. 
the asset's sale price $V(s)$ in state $\mathrm{s}$ and its initial book value. For a tax-free asset owner, the payoff on the exercise date is the final rent plus either the exercise price or the asset's market value.

In a binomial framework, only two outcomes need be analyzed at each point one-period before the exercise date. Then risk neutral synthetic probabilities can be used to calculate the discounted expected value of the two outcomes. The problem is to use the proper discount rate for each possible outcome. First consider the loan repayment. Given no possibility of default, a one-period discount rate for loan repayment can be solved directly. ${ }^{4+t} \mathrm{~A}$ taxable lessor must make an after-tax loan repayment payment of $B(0)+(1-T) C$ and a tax-free lessor must make a loan repayment of $B(0)+C$. Following the previous analysis of discount rates when simple tax arbitrage is precluded, the present values of the two payments can be equated to solve for the proper after-tax discount rate for the taxable lessor.

\section{$(B(0)+C(1-T)) /(1+r(0))=(B(0)+C) /\left(1+r_{1}(0)\right)$}

Solving this expression for the after-tax discount rate in terms of the pre-tax riskfree rate gives:

$$
\left.r(0)=r_{1}(0)(1-(C T /(B+C)))-(C T / B+C)\right)
$$

If the initial loan was established with the coupon rate set so that $\mathrm{C}=r_{1}(0) \mathrm{B}(0)$, then the after-tax discount rate is $r(0)=r_{1}(0)(1-T)$, which is the result for the after-tax discount rate from the first section.

Next consider the option payoff conditions. Using the same no tax arbitrage logic, the appropriate after-tax discount rate for an option exercise outcome can be calculated by equating the taxable and tax-free payoffs.

$(V(0)+(Z+R-V(0))(1-T)) /(1+r(0))=(Z+R) /\left(1+r_{1}(0)\right)$

Again, solving this expression for $r(0)$ gives the after-tax discount rate to apply to exercise date states in which the lease option will be exercised.

$$
\boldsymbol{r}(0)=r_{1}(0)(1-T(1-V(0) /(Z+R))-T(1-V(0) /(Z+R))
$$

To calculate the after-tax discount rate for the no option exercise by the lessee outcome, the same logic can be used by equating the nontaxable lessor and taxable lessor payoff values. The results are quite similar to the exercise results, except that $V(s)$ replaces $Z$. Here $\mathrm{s}$ represents either an up or down increment in value, whichever state occurs at the payoff. The after-tax discount rate for no exercise payoffs is:

$r(0)=r_{1}(0(1-T(1-V(0) /(V(s)+R)))-T(1-V(0) /(V(s)+R))$

To value payoff outcomes one time period before exercise, apply the appropriate discount rate to each outcome one-period hence. If the option is in the money at an outcome, discount the after-tax payoff from exercise with the after-tax exercise discount factor and multiply the present value times the appropriate risk neutral probability. If the option is out of the money, use the no exercise after-tax discount factor to calculate the after-tax payoff's present value and multiply this to the appropriate risk neutral probability. Next we use a simple numerical example to illustrate this.

\section{A SIMPLE EXAMPLE OF THE LEASE TRANSACTION ANALYSIS}

The following example illustrates how to derive the proper after-tax discount rate for an asset that has state-contingent payoffs in a risk-neutral world. This example is based on the following assumptions:

\footnotetext{
4 This analysis assumes that financial arrangements (letters of credit or payment undertakings)
} are such that no loan or lease default will occur. 
1. The asset is purchased at the beginning of the period, and it is depreciated using a 30-year straight-line method with no salvage value.

2. Except for depreciation expenses, there are no other periodic expenses associated with the use of the asset.

3. The asset owner (lessor) has a single marginal tax rate, whether his income is ordinary income or a capital gain.

The following notations are used in the example:

$v_{0}:$ initial purchase price of the asset, or asset value at period 0 .

$N$ : depreciation period.

$T$ : lessor's marginal tax rate.

$r_{\mathrm{f}}:$ pre-tax risk free rate.

$Z$ : lessee's purchase price of the asset at the end of the lease term.

$\sigma_{\mathrm{v}}:$ standard deviation of asset return per period.

$\mu_{\mathrm{v}}:$ mean of return of asset value per period.

$\psi:$ mean of return of holding the asset per period.

Let $v_{0}=\$ 1000$ and $N=30$, then:

1. Periodic depreciation expense: $d=(1000-0) / 30=\$ 33.33$.

2. Asset book value at the end of period 1: $B V_{\mathrm{t}+1}=1000-33.33=\$ 966.67$.

3. Similarly, asset book value at the end of period 2: $B V_{\mathrm{t}+2}=966.67-33.33=\$ 933.34$.

4. Given the asset's book value, the capital gain is calculated as the difference between the market value and the book value of the asset, i.e. $\boldsymbol{G}_{\mathbf{t}}=\boldsymbol{V}_{\mathbf{t}}-\boldsymbol{B} \boldsymbol{V}_{\mathbf{t}}$.

The example does the following:

1. Calculates the binomial two-period state-contingent asset values, assuming riskneutral probabilities.

2. Calculates the cash flow with the use of the asset in each period; note that cash flow is also state-contingent.

3. Calculates the discounted price, given the state-contingent payoff of the asset, using the pre-tax risk free rate.

4. Calculates the asset's state-contingent after-tax payoffs for a taxable lessor, given that operating income from the use of the asset and the capital gain from liquidating the asset (purchased by the lessee or others) are both taxable. Operating income is defined as the asset's cash flow minus the asset's periodic depreciation expense.

5. Given that both taxable and tax-free asset traders/investors pay the same price for the asset in a tax arbitrage-limited market, solves the after-tax discount rate on aftertax payoffs by equating the pre-tax discounted price with the after-tax discounted price.

\section{TWO-PERIOD BINOMIAL ASSET VALUE AND CASH FLOW PROCESS}

Assume the asset value underlying the lease evolves in two periods in the following fashion:

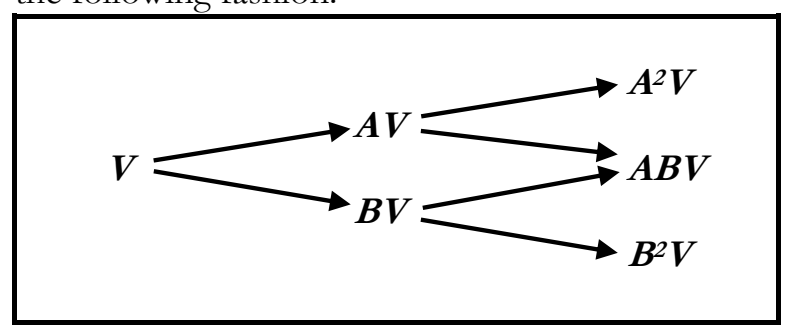


Where $A=e^{\mathrm{a}}$ and $B=e^{\mathrm{b}}$, with $A>B$, and probability of $A$ is equal to $q$ under the riskneutral measure. The use of the asset is associated with a cash flow process that can be characterized by the following binomial process:

$$
\mathrm{C}_{(\mathrm{t}+1)}=\left\{\begin{array}{l}
V_{(\mathrm{t})} \mathrm{e}^{\mathrm{a}}\left(\mathrm{e}^{\left(\mathrm{r}_{\mathrm{f}}+\lambda\right)}-1\right) w / \text { probability } q \\
V_{(\mathrm{t})} \mathrm{e}^{\mathrm{b}}\left(\mathrm{e}_{\mathrm{f}}^{\left.\mathrm{r}_{\mathrm{f}}+\lambda\right)}-1\right) \text { probability } 1-q
\end{array}\right.
$$

Let $q=1 / 2$; we have:

$\lambda=\Psi-\mu_{\mathrm{v}}$

$\mathrm{b}=-\lambda+\log \frac{2}{\mathrm{e}^{2 \sigma_{\mathrm{v}}}+1}$

$\mathrm{a}=-\lambda+\log \frac{2 \mathrm{e}^{2 \sigma_{\mathrm{v}}}}{\mathrm{e}^{2 \sigma_{\mathrm{v}}}+1}$

In this example, let $T=40 \%, \mathrm{r}_{\mathrm{f}}=10 \%, Z=\$ 1010, \sigma_{\nu}=15 \%, \mu_{\nu}=-3 \%$, and $\omega=2 \%\left(\mu_{\nu}, \sigma_{\nu}\right.$, and $\omega$ can be empirically estimated $)$; we have:

$\lambda=2 \%-(-3 \%)=5 \%$

$$
\begin{aligned}
& \mathrm{A}=\mathrm{e}^{\mathrm{a}}=\mathrm{e}^{-\lambda+\log \frac{2 \mathrm{e}^{2 \sigma_{\mathrm{v}}}}{\mathrm{e}^{2 \sigma_{\mathrm{v}}+1}}} \approx 1.09285325 \\
& \mathrm{~B}=\mathrm{e}^{\mathrm{b}}=\mathrm{e}^{-\lambda+\log \frac{2}{\mathrm{e}^{2 \sigma_{\mathrm{v}}}+1}} \approx 0.80960560
\end{aligned}
$$
following:

Therefore, we can derive the two-period asset value binomial tree as the

$$
\begin{aligned}
& V_{t+1}=\left\{\begin{array}{l}
V_{u}=V_{0} * A \approx 1092.85324935 \\
V_{d}=V_{0} * B \approx 809.60559965
\end{array}\right. \\
& V_{t+2}=\left\{\begin{array}{l}
V_{\mathrm{uu}}=V_{\mathrm{u}}^{*} A \approx 1194.32822462 \\
V_{u d}=V_{\mathrm{du}}=\mathrm{A}^{*} \mathrm{~B}^{*} V_{0} \approx 884.78011027 \\
V_{\mathrm{dd}}=V_{\mathrm{d}} * B \approx 655.46122699
\end{array}\right.
\end{aligned}
$$

\subsection{Payoff to Tax-Free Asset Holders}

There are two types of potential payoffs to a tax-free asset holder in each period and each state: cash flow from using the asset $\left(C_{t}\right)$ and asset value $\left(V_{t}\right)$. Plugging in the parameter values, we get:

$$
C_{t+1}=\left\{\begin{array}{l}
C_{u}=V_{u}^{*}\left(\mathrm{e}_{\mathrm{f}}^{\mathrm{r}_{\mathrm{f}}+\lambda}-1\right) \approx 176.86107802 \\
C_{d}=V_{d}^{*}\left(\mathrm{e}_{\mathrm{f}}^{\mathrm{r}}+\lambda_{-}\right) \approx 131.02190913
\end{array}\right.
$$

Therefore, if the asset is liquidated at the end of period 1, payoffs to a tax-free asset holder equal:

$$
\begin{gathered}
\left\{\begin{array}{l}
V_{u}+C_{u} \approx 1269.71432737 \\
V_{d}+C_{d} \approx 940.62750878
\end{array}\right. \\
\text { Similarly, period two cash flows equal: }
\end{gathered}
$$

And the total payoffs to a tax-free asset holder if the asset is liquidated at the end of period 2 equal:

$$
\left\{\begin{array}{l}
V_{u u}+C_{u u} \approx 1387.6114 \\
V_{d d}+C_{d d} \approx 761.5373 \\
V_{u d}+C_{u d}=V_{d u}+C_{d u} \approx 1027.9678
\end{array}\right.
$$

It can be shown that under no arbitrage condition to the total payoff, the discounted expected value of the total payoff in one-period (two-periods) exactly equals current asset value, i.e. 1000. 
For a one-period model, $e^{\mathrm{rf}}\left[q^{*}\left(V_{u}+C_{u}\right)+(1-q) *\left(V_{d}+C_{d}\right)\right]=V_{0}$

Plugging in the numbers, we get: $\mathrm{e}^{-10 \% *}(0.5 * 1269.71432737+0.5 * 940.62750878)=1000$

For a two-period model, $e^{-r f *}\left[q^{*} C_{\mathrm{u}}+(1-q) C_{\mathrm{d}}\right]+e^{-2 r r}\left[q^{2 *}\left(V_{\mathrm{uu}}+C_{\mathrm{uu}}\right)+(1-q)^{2 *}\left(V_{\mathrm{dd}}+C_{\mathrm{dd}}\right)+2 q^{*}(1-q) *\left(V_{\mathrm{ud}}+C_{\mathrm{ud}}\right)\right]=V_{0}$ Plugging in the numbers, we get:

$e^{-10 \% *}\left[\left(.5 * C_{\mathrm{u}}+.5^{*} C_{\mathrm{d}}\right)+e^{-2 * 10 \%}\right] *\left[.25\left(V_{\mathrm{uu}}+C_{\mathrm{uu}}\right)+.25\left(V_{\mathrm{dd}}+C_{\mathrm{dd}}\right)+2 * .25\left(V_{\mathrm{ud}}+C_{\mathrm{ud}}\right)\right]=1000$

\subsection{Payoff to Taxable Asset Holders}

For a taxable asset holder, both operating income $I_{t}$ from using the asset, which is defined as cash flow minus periodic depreciation expense $\left(C_{\mathrm{t}}-\mathrm{d}\right)$, and capital gains from liquidating the asset $\left(G_{t}\right)$ are taxable.

In particular,

$$
\begin{aligned}
& G_{\mathrm{t}+1}=V_{\mathrm{t}+1}-B V_{\mathrm{t}+1}=\left\{\begin{array}{l}
G_{\mathrm{u}}=V_{\mathrm{u}}-B V_{\mathrm{t}+1}=V_{\mathrm{u}}-V_{0}+d \approx 126.18658268 \\
G_{\mathrm{d}}=V_{\mathrm{d}}-B V_{\mathrm{t}+1}=V_{\mathrm{d}}-V_{0}+d \approx-157.06106702
\end{array}\right. \\
& I_{\mathrm{t}+1}=C_{\mathrm{t}+1-} d=\left\{\begin{array}{l}
I_{\mathrm{u}}=C_{\mathrm{u}}-d \approx 143.52774469 \\
I_{\mathrm{d}}=C_{\mathrm{d}}-d \approx 97.68857579
\end{array}\right.
\end{aligned}
$$

Therefore, the total after-tax payoff if the asset is liquidated at the end of period 1 can be calculated as:

$B V_{\mathrm{t}+1}+(1-T) *\left(G_{\mathrm{t}+1}+I_{\mathrm{t}+1}\right) ;$ or $V_{\mathrm{t}+1}-T^{*} G_{\mathrm{t}+1}+(1-T)^{*} I_{t+1}$

Both yield the same result on the total after-tax payoff:

$$
\left\{\begin{array}{l}
B V_{\mathrm{t}+1}+(1-T)^{*}\left(G_{\mathrm{u}}+I_{\mathrm{u}}\right)=V_{0^{-}} d+(1-T)^{*}\left(V_{\mathrm{u}}-V_{0}+C_{\mathrm{u}}\right) \approx 1128.49526309 \\
B V_{\mathrm{t}+1}+(1-T)^{*}\left(G_{\mathrm{d}}+I_{d}\right)=V_{0^{-}}-d+(1-T)^{*}\left(V_{\mathrm{d}}-V_{0}+C_{\mathrm{d}}\right) \approx 931.04317193
\end{array}\right.
$$

Notice that the after-tax payoff is not equal to after-tax cash flow; to get after-tax cash flow, we need to add back the noncash charge, depreciation expense. After-tax cash flow in one-period equals:

$$
\left\{\begin{array}{l}
V_{0}+(1-T)^{*}\left(V_{\mathrm{u}}-V_{0}+C_{\mathrm{u}}\right)=V_{\mathrm{u}}+C_{\mathrm{u}}-T^{*}\left(V_{\mathrm{u}}-V_{0}+C_{\mathrm{u}}\right) \approx 1161.82859642 \\
V_{0}+(1-T)^{*}\left(V_{\mathrm{d}}-V_{0}+C_{\mathrm{d}}\right)=V_{\mathrm{d}}+C_{\mathrm{d}}-T^{*}\left(V_{\mathrm{d}}-V_{0}+C_{\mathrm{d}}\right) \approx 964.37650527
\end{array}\right.
$$

Given no tax arbitrage, both taxable and tax-free investors should pay the same price to purchase the asset at time 0 . Thus the expected value of total after-tax cash flow, discounted at the after-tax discount rate in one-period, should equal the current asset value, i.e. 1000 .

Let $r_{1}$ be the one-period after-tax discount rate; we can solve $r_{1}$ from the following equation:

$$
\mathrm{e}^{-\mathrm{r}_{1}}\left\{q^{*}\left[V_{\mathrm{u}}+C_{\mathrm{u}}-T^{*}\left(V_{\mathrm{u}}-V_{0}+C u\right)\right]+(1-q) *\left[V_{\mathrm{d}}+C_{\mathrm{d}}-T^{*}\left(V_{\mathrm{d}}-V_{0}+C_{\mathrm{d}}\right)\right]\right\}=V_{0}
$$

We can solve $\mathrm{r}_{1}$ as:

$$
\mathrm{r}_{1}=\log \left\{\frac{\mathrm{q} *\left[\mathrm{~V}_{\mathrm{u}}+\mathrm{C}_{\mathrm{u}}-\mathrm{T} *\left(\mathrm{~V}_{\mathrm{u}}-\mathrm{V}_{0}+\mathrm{C}_{\mathrm{u}}\right)\right]+(1-\mathrm{q}) *\left[\mathrm{~V}_{\mathrm{d}}+\mathrm{C}_{\mathrm{d}}-\mathrm{T} *\left(\mathrm{~V}_{\mathrm{d}}-\mathrm{V}_{0}+\mathrm{C}_{\mathrm{d}}\right)\right]}{\mathrm{V}_{0}}\right\}
$$

Where:

$$
V_{0}=\mathrm{e}^{-\mathrm{r}_{\mathrm{f}}}\left[q^{*}\left(V_{\mathrm{u}}+C_{\mathrm{u}}\right)+(1-q) *\left(V_{\mathrm{d}}+C_{\mathrm{d}}\right)\right]
$$

Solving the above equation, we can get:

$$
\mathrm{r}_{1}=\mathrm{r}_{\mathrm{f}}+\log \left(1-\mathrm{T}+\frac{\mathrm{T} * \mathrm{~V}_{0}}{\mathrm{q} *\left(\mathrm{~V}_{\mathrm{u}}+\mathrm{C}_{\mathrm{u}}\right)+(1-\mathrm{q}) *\left(\mathrm{~V}_{\mathrm{d}}+\mathrm{C}_{\mathrm{d}}\right)}\right)
$$


Let $\mathrm{E}_{\mathrm{t}}^{\mathrm{Q}}\left(V_{\mathrm{t}+1}+C_{\mathrm{t}+1}\right)$ be the expected value of the total payoff of the asset in the next period, under the risk-neutral measure. We can rewrite the above equation as:

$$
\mathrm{r}_{1}=\mathrm{r}_{\mathrm{f}}+\log \left(1-\mathrm{T}+\frac{\mathrm{T} * \mathrm{~V}_{0}}{\mathrm{E}_{\mathrm{t}}^{\mathrm{Q}}\left(\mathrm{V}_{\mathrm{t}+1}+\mathrm{C}_{\mathrm{t}+1}\right)}\right)
$$

Plugging in the numbers, we have:

$$
\begin{aligned}
& \mathrm{e}^{-\mathrm{r}_{1}} *(.5 * 1161.82859642+.5 * 964.37650527)=1000 \\
& \mathrm{r}_{1}=10 \%+\log \left(1-0.4+\frac{0.4 * 1000}{1105.17091808}\right) \approx 0.06119157
\end{aligned}
$$

Notice that the accounting depreciation expense does not affect the after-tax cash flow and, therefore, the after-tax discount rate if the asset is liquidated after oneperiod (Hulten \& Wykoff, 1981a, 1981b). Similarly, we can derive the two-period aftertax discount rate as the following:

$$
\begin{aligned}
& G_{t+2}=V_{t+2}-B V_{t+2}=\left\{\begin{array}{l}
G_{u u}=V_{u u^{-}} B V_{t+2}=V_{u u^{-}} V_{0}+2 d \approx 260.9949 \\
G_{d d}=V_{d t^{-}} B V_{t+2}=V_{d t^{-}} V_{0}+2 d \approx-277.8721 \\
G_{u d}=G_{d u}=V_{u t} B V_{t+2}=V_{u t^{-}} V_{0}+2 d \approx-48.5532
\end{array}\right. \\
& I_{t+2}=C_{t+2^{-}} d=\left\{\begin{array}{l}
I_{u u}=C_{u u^{-}} d \approx 159.9499 \\
I_{d d^{2}}=C_{d d^{-}} d \approx 72.7427 \\
I_{u d}=I_{d u^{-}}=C_{u d^{-}} d \approx 109.8544
\end{array}\right.
\end{aligned}
$$
2, equal:

Thus, after-tax payoffs in period 2, if the asset is liquidated at the end of period

$$
\left\{\begin{array}{l}
B V_{t+2}+(1-T)^{*}\left(G_{u u}+I_{u u}\right)=V_{0^{-}} 2 d+(1-T)^{*}\left(V_{u u^{-}} V_{0}+V_{u u}+d\right) \approx 1185.9002 \\
B V_{t+2}+(1-T)^{*}\left(G_{d d}+I_{d d}\right)=V_{0^{-}}-2 d+(1-T)^{*}\left(V_{d d^{-}} V_{0}+V_{d d}+d\right) \approx 810.2557 \\
B V_{t+2}+(1-T)^{*}\left(G_{u d}+I_{u d}\right)=V_{0-} 2 d+(1-T)^{*}\left(V_{u d^{-}} V_{0}+V_{u d}+d\right) \approx 970.1140
\end{array}\right.
$$

Again, by adding depreciation expense back to the payoff to get after-tax cash flow, we can get after-tax cash flow for period 1 :

$$
\begin{aligned}
& \left\{\begin{array}{l}
(1-T) I_{u}+d=(1-T)^{*}\left(C_{u^{-}}-d\right)+d=(1-T)^{*} C_{u}+T^{*} d \approx 119.44998 \\
(1-T) I_{d}+d=(1-T)^{*}\left(C_{d^{-}} d\right)+d=(1-T)^{*} C_{d}+T^{*} d \approx 91.94648
\end{array}\right. \\
& \text { We can also get after-tax cash flow for period } 2: \\
& \left\{\begin{array}{l}
V_{0^{-}} d+(1-T)^{*}\left(V_{u u^{-}} V_{0}+C_{u u}+d\right) \approx 1219.23352 \\
V_{0^{-}} d+(1-T)^{*}\left(V_{d c^{-}} V_{0}+C_{d d}+d\right) \approx 843.58905 \\
V_{0^{-}}+(1-T)^{*}\left(V_{u c^{-}} V_{0}+C_{u d}+d\right) \approx 1003.44736
\end{array}\right.
\end{aligned}
$$

Let $r_{2}$ be the two-period after-tax discount rate; applying the no-tax-arbitrage condition to the two-period after-tax payoff yields the following:

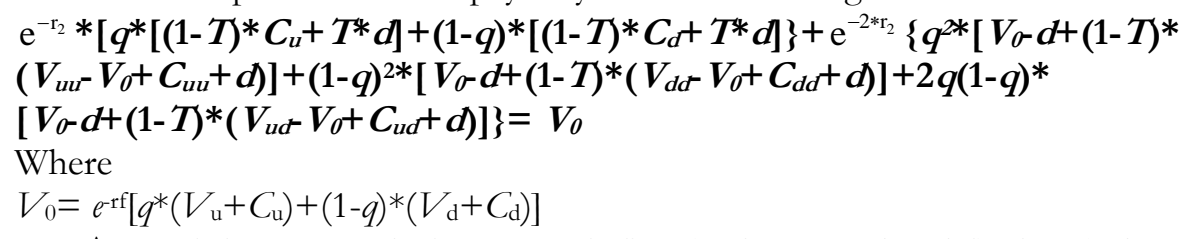


Plugging in the numbers, we get:

$$
\begin{aligned}
& A=.25 * 1219.23352+.25 * 843.58905+.5 * 1003.44736 \approx 1017.4293 \\
& B=.5 * 119.44998+.5 * 91.94648 \approx 105.69823
\end{aligned}
$$$$
\mathrm{r}_{2}=-\log \left(\frac{-105.69823+\sqrt{105.69823^{2}+41017.4293 * 1000}}{2 * 1017.4293}\right) \approx 0.0610
$$

Notice that accounting depreciation affects the taxes paid by the asset holder and thus affects the after-tax cash flows but not the after-tax discount rate (but for rounding).

\section{1) The Lease Example - One Period}

Now suppose the asset is a leased asset that gives the lessee a right to purchase the asset at a fixed price of $Z=\$ 1,010$ at the end of period 1 . The lessee will exercise the option if $V_{\mathrm{t}+1}>Z$; otherwise, the lessee's option will not be exercised.

Given that

$$
V_{t+1}=\left\{\begin{array}{l}
V_{u}=V_{0} * A \approx 1092.85324935 \\
V_{d}=V_{0} * B \approx 809.60559965
\end{array}\right.
$$

The option is exercised if the asset value ends up at $V_{u}$. From the lessor's point of view, option exercise by the lessee triggers a taxable event to the lessor if the lessor is taxable. We can compare the payoffs to both a taxable lessor and a tax-free lessor.

\section{a) When the Option is Exercised}

Payoff to a tax-free lessor:

$Z+C_{u} \approx 1186.86107802$

Payoff to a taxable lessor:

$B V_{t+1}+(1-T)^{*}\left(Z+C_{u^{-}} V_{0}\right)=V_{0^{-}} d+(1-T)^{*}\left(Z+C_{u^{-}} V_{0}\right) \approx 1078.78331348$

After-tax cash flow to a taxable lessor:

$V_{0}+(1-T) *\left(Z+C_{u}-V_{0}\right) \approx 1112.11664681$

Applying the tax-arbitrage-limit condition, we get the one-period after-tax discount rate if the option is exercised $\left(r_{1}^{e}\right)$ :

$$
\mathrm{r}_{1}^{\mathrm{e}}=\log \left(\frac{\mathrm{e}^{\mathrm{r}_{\mathrm{f}}}\left[\left(\mathrm{V}_{0}+(1-\mathrm{T}) *\left(\mathrm{Z}+\mathrm{C}_{\mathrm{u}}-\mathrm{V}_{0}\right)\right]\right.}{\mathrm{Z}+\mathrm{C}_{\mathrm{u}}}\right) \approx 0.03495302
$$

\section{b) When the Option is Not Exercised}

This is the down state situation in period 1. The payoff to a tax-free lessor is:

$V_{d}+C_{d} \approx 940.62750878$

Payoff to a taxable lessor:

$B V_{t+1}+(1-T)^{*}\left(V_{d}+C_{d^{-}} V_{0}\right)=V_{0^{-}} d+(1-T)^{*}\left(V_{d}+C_{d^{-}} V_{0}\right) \approx 931.04317193$

After-tax cash flow to a taxable lessor:

$$
V_{0}+(1-T)^{*}\left(V_{d}+C_{d^{-}} V_{0}\right) \approx 964.37650527
$$

Applying the tax-arbitrage-limit condition, we get the one-period after-tax discount rate if the option is not exercised $\left(\mathrm{r}_{1}^{\mathrm{ne}}\right)$ :

$$
\mathrm{r}_{1}^{\mathrm{ne}}=\log \left(\frac{\mathrm{e}^{\mathrm{r}_{\mathrm{f}}}\left[\left(\mathrm{V}_{0}+(1-\mathrm{T}) *\left(\mathrm{~V}_{\mathrm{d}}+\mathrm{C}_{\mathrm{d}}-\mathrm{V}_{0}\right)\right]\right.}{\mathrm{V}_{\mathrm{d}}+\mathrm{C}_{\mathrm{d}}}\right) \approx 0.12493457
$$

The after-tax discount rate is much lower with option exercise than the after-tax discount rate without option exercise.

\section{2) The Lease Example - Two Period}

Now suppose the asset is a leased asset that gives the lessee a right to purchase the asset at a fixed price of $Z=\$ 1,010$ at the end of period 2. The lessee will exercise the option if $V_{t+2}>Z$; otherwise, the lessee's option will not be exercised. 


$$
V_{t+2}=\left\{\begin{array}{l}
V_{u n}=V_{u}^{*} A \approx 1194.32822462 \\
V_{u d}=V_{d u}=A^{*} B^{*} V_{0} \approx 884.78011027 \\
V_{d d}=V_{d}^{*} B \approx 655.46122699
\end{array}\right.
$$

The option is exercised if the asset value ends up at $V_{u n}$ at the end of period 2. From the lessor's point of view, option exercise by the lessee triggers a taxable event to the lessor if the lessor is taxable. We can compare the payoffs to both a taxable lessor and a tax-free lessor.

\section{a) When the Option is Exercised}

Let $V_{f 1}$ be the discounted payoff to a tax-free lessor:

$V_{f l}=\mathrm{e}^{-\mathrm{r}_{\mathrm{f}}} C_{u}+\mathrm{e}^{-2 * \mathrm{r}_{\mathrm{f}}}\left(Z+C_{u u}\right) \approx 1145.195485$

Let $\mathrm{r}_{2}^{\mathrm{e}}$ be the two-period after-tax discount factor with option exercise; the discounted payoff to a taxable lessor is:

$$
\mathrm{e}^{-\mathrm{r}_{2}^{\mathrm{e}}}\left[(1-T) *\left(C_{u^{-}} \boldsymbol{d}\right)+d\right]+\mathrm{e}^{-2 * \mathrm{r}_{2}^{\mathrm{e}}}\left[\boldsymbol{V}_{\boldsymbol{\sigma}^{-}} \boldsymbol{d}+(1-T) *\left(\mathrm{Z}+\boldsymbol{C}_{u u^{-}} \boldsymbol{V}_{\boldsymbol{\sigma}}+\boldsymbol{d}\right)\right]
$$

Let $A$ be the after-tax cash flow to a taxable lessor in the second and final period; thus,

$$
A=V_{0^{-}} d+(1-T)^{*}\left(Z+C_{u u^{-}} V_{0^{\prime}}+d\right)
$$

Let $B$ be the after-tax cash flow to a taxable lessor in the first period; thus,

$B=(1-T) *\left(C_{u}-d\right)+d=(1-T) * C_{u}+T^{*} d$

By equating the two discounted payoffs to both tax-free and taxable lessors, we can solve the two-period after-tax discount rate if the option is exercised $\left(\mathrm{r}_{2}^{\mathrm{e}}\right)$ :

$$
\left.\mathrm{r}_{2}^{\mathrm{e}}=-\log \left\{-B+\left(B^{2+}+4 A V_{f i}\right)^{1 / 2}\right] /[2 A]\right\}
$$

Plugging in the numbers, we get:

$$
r_{2}^{\mathrm{e}}=\mathbf{0 . 0 3 6 7 5 8 6 0 5}
$$

\section{b) When the Option is not Exercised}

This can be the case when the asset value ends up at $V_{d d}, V_{u d}$, or $V_{d u}$ at the end of period 2 .

When the asset value ends up at $V_{d d}$

Let $V_{f 2}$ be the discounted payoff to a tax-free lessor:

$V_{f 2}=\mathrm{e}^{-\mathrm{r}_{\mathrm{f}}} C_{d}+\mathrm{e}^{-2 * \mathrm{r}_{\mathrm{f}}}\left(V_{d d}+C_{d d}\right) \approx 742.04753$

Let $r_{2}^{\text {dd }}$ be the two-period after-tax discount factor without option exercise with a down-down two-period path; the discounted payoff to a taxable lessor is:

$$
\mathrm{e}^{-\mathrm{r}_{2}^{\mathrm{dd}}}\left[(1-T) *\left(C_{d}-d\right)+d\right]+\mathrm{e}^{-2 * \mathrm{r}_{2}^{\mathrm{dd}}}\left[\boldsymbol{V}_{\boldsymbol{\sigma}}-\boldsymbol{d}+(1-T) *\left(V_{d d}+C_{d \boldsymbol{d}} \boldsymbol{V}_{\boldsymbol{o}}+\boldsymbol{d}\right)\right]
$$

Let $A$ be the after-tax cash flow to a taxable lessor in the second and final period; thus,

\section{$\mathrm{A}=V_{\sigma^{-}} d+(1-T) *\left(V_{d d}+C_{d d}-V_{\sigma}+d\right)$}

Let $B$ be the after-tax cash flow to a taxable lessor in the first period; thus,

$$
B=(1-T) *\left(C_{d^{-}} d\right)+d=(1-T) * C_{d}+T^{*} d
$$

By equating the two discounted payoffs to both tax-free and taxable lessors, we can solve the two-period after-tax discount rate if the option is exercised $\left(r_{2} \mathrm{dd}\right)$ :

$\mathrm{r}_{2}^{\mathrm{dd}}=-\log \left\{\left[-B+\left(B^{2+4 A} \boldsymbol{V}_{f 2}\right)^{1 / 2}\right] /[2 A]\right\}$

Plugging in the numbers, we get:

$$
r_{2}^{\mathrm{dd}}=0.122199805
$$

When the asset value ends up at $V_{u d}$ via an up-down path. 
Let $V_{f 3}$ be the discounted payoff to a tax-free lessor:

$V_{f 3}=\mathrm{e}^{-\mathrm{r}_{\mathrm{f}}} C_{u}+\mathrm{e}^{-2 * \mathrm{r}_{\mathrm{f}}}\left(V_{u d}+C_{u d}\right) \approx 1001.65940$

Let $r_{2}$ ud be the two-period after-tax discount factor without option exercise with an up-down two-period path; the discounted payoff to a taxable lessor is:

$\mathrm{e}^{-\mathrm{r}_{2}^{\text {ud }}}\left[(1-T) *\left(C_{u}-\boldsymbol{d}\right)+\boldsymbol{d}\right]+\mathrm{e}^{-2 * \mathrm{r}_{2}^{\text {ud }}}\left[\boldsymbol{V}_{\boldsymbol{\sigma}} \boldsymbol{d}+(1-T) *\left(\boldsymbol{V}_{u d}+\boldsymbol{C}_{u d} \boldsymbol{V}_{\boldsymbol{o}}+\boldsymbol{d}\right)\right]$

Let $A$ be the after-tax cash flow to a taxable lessor in the second and final period; thus,

$A=V_{v}-d+(1-T) *\left(V_{u d}+\mathrm{C}_{u d}-V_{0}+d\right)$

Let $B$ be the after-tax cash flow to a taxable lessor in the first period; thus,

$B=(1-T) *\left(C_{u}-d\right)+d=(1-T) * C_{u}+T * d$

By equating the two discounted payoffs to both tax-free and taxable lessors, we can solve the two-period after-tax discount rate if the option is exercised $\left(r_{2}{ }^{\text {ud }}\right)$ :

$\mathrm{r}_{2}^{\text {ud }}=-\log \left\{\left[-B+\left(B^{2+4 A} \boldsymbol{V}_{f 3}\right)^{1 / 2}\right] /[2 A]\right\}$

Plugging in the numbers, we get:

$r_{2}{ }^{\text {ud }}=0.060429428$

When the asset value ends up at $V_{u d}$ via a down-up path.

Let $V_{f 4}$ be the discounted payoff to a tax-free lessor:

$V_{f 4}=\mathrm{e}^{-\mathrm{r}_{\mathrm{f}}} C d+\mathrm{e}^{-2 * \mathrm{r}_{\mathrm{f}}}(V u d+C u d) \approx 960.18240$

Let $r_{2}^{\text {ud }}$ be the two-period after-tax discounted factor without option exercise with a down-up two-period path; the discounted payoff to a taxable lessor is:

$\mathrm{e}^{-\mathrm{r}_{2}^{\mathrm{du}}}\left[(\mathbf{1}-\boldsymbol{T}) *\left(\boldsymbol{C}_{\mathrm{d}}-\boldsymbol{d}\right)+\boldsymbol{d}\right]+\mathrm{e}^{-2 * \mathrm{r}_{2}^{\mathrm{du}}}\left[\boldsymbol{V}_{\mathbf{0}}-\boldsymbol{d}+(1-T) *\left(\boldsymbol{V}_{\text {ud }}+\boldsymbol{C}_{\text {ud }}-\boldsymbol{V}_{\mathbf{0}}+\boldsymbol{d}\right)\right]$

Let $\mathrm{A}$ be the after-tax cash flow to a taxable lessor in the second and final period; thus,

$A=V_{0}-d+(1-T) *\left(V_{\text {ud }}+C_{\text {ud }}-V_{0}+\mathrm{d}\right)$

Let $\mathrm{B}$ be the after-tax cash flow to a taxable lessor in the first period; thus,

$B=(1-T) *\left(C_{d}-d\right)+d=(1-T) * C d+T * d$

By equating the two discounted payoffs to both tax-free and taxable lessors, we can solve the two-period after-tax discount rate if the option is exercised $\left(r_{2}{ }^{\mathrm{du}}\right)$ :

$\mathrm{r}_{2}^{\mathrm{du}}=-\log \left\{\left[-B+\left(B^{2}+4 A \boldsymbol{V}_{f 4}\right)^{1 / 2}\right] /[2 A]\right\}$

Plugging in the numbers, we get:

$\mathrm{r}_{2}^{\mathrm{du}}=\mathbf{0 . 0 6 8 8 5 5 7 3 7}$

The after-tax discount rate is path-dependent. It is lowest with the exercise of the option and highest with no option exercise via a down-down two-period path. All else equal, the more the down asset value movement and the earlier the down asset value movement, the higher the after-tax discount rate.

\section{CONCLUSIONS}

This research note addresses after-tax discounting for pricing assets. Specifically, it shows that in tax arbitrage-limited markets, both taxable and tax-free instruments appear to trade on an after-tax basis with taxable and tax-free investors and issuers. Secondly, it derives the after-tax discount rate to use in the risk neutral valuation method for pricing assets that have state-contingent payments, typically structured in a lease based transaction. It shows that in pricing leased asset, the after-tax discount rate is much lower with option exercise by lessee to purchase the asset at the end of the lease than the after-tax discount rate without option exercise and is path-dependent. 


\section{REFERENCES}

Al-Abadi, M. I., \& Al-Sabbagh, O. W. (2006, October). Interest rate sensitivity, market risk, inflation and bank stock returns. Journal of Accounting - Business \& Management, 13(1), 1-13.

Hulten, C. R., \& Wykoff, F. C. (1981a, January). The measurement of economic depreciation. In Depreciation, Inflation, and the Taxation of Income from Capital (pp. 81125). Washington, D. C.: The Urban Institute Press.

Hulten, C. R., \& Wykoff, F. C. (1981b, April). The estimation of economic depreciation using vintage asset prices. Journal of Econometrics, 15(3), 367-396.

Jarrow, R. A., \& Rudd, A. T. (1983, January). Option Pricing. Homewood, Illinois: Richard D. Irwin, Inc. 